\title{
Hannah Arendt e a política sem piedade
}

\section{Ricardo Luiz de Souza*}

eixo temático por mim proposto é a análise do pensamento de Hannah Arendt no que se refere à ação política em conexão com duas questões que, por assim dizer, estão presentes no horizonte teórico da autora e, ao mesmo tempo, assombraram-no, a saber: o advento do totalitarismo e a ascensão das massas no mundo moderno. A autora define essas questões como intimamente relacionadas, e os aspectos do pensamento político arendtiano serão aqui abordados com base no eixo temático proposto.

Podemos começar com algumas questões a respeito da teoria política arendtiana. Inicialmente, o que é o poder para Hannah Arendt? A autora assim o define: "O poder corresponde à habilidade humana de não apenas agir, mas de agir em uníssono, em comum acordo. O poder jamais é propriedade de um indivíduo; pertence ele a um grupo e existe apenas enquanto o grupo se mantiver unido" (ARENDT, 1985, p. 24). Já a violência é a ruptura do acordo e, portanto, a dissolução do poder: "À violência sempre é dado destruir o poder; do cano de uma arma desponta o domínio mais eficaz, que resulta na mais perfeita e imediata obediência. O que jamais poderá florescer da violência é o poder" (idem, p. 29). O poder, portanto, nasce sempre do acordo, jamais da violência.

* Ricardo Luiz de Souza é Doutor em História pela Universidade Federal de Minas Gerais (UFMG) e Professor do Centro Universitário de Sete Lagoas (UNIFEMM). Endereço eletrônico: riclsouza@uol.com.br. 
A violência não é vista por Arendt, como acentua Wagner (2002, p. 118), como um fenômeno político, "além disso, por não estar assentada na palavra e na ação, ela é, sempre, destituída de dignidade e de grandeza". E violência para Arendt, portanto, não é poder, nascendo, antes, de sua ausência: "Falando genericamente, a violência sempre brota da impotência. É a esperança daqueles que não têm poder [consentimento ou apoio do povo] de encontrar um substituto para ele - e essa esperança, penso, é em vão" (Arendt apud YOUNG-BRUHEL, 1997, p. 363).

A violência é situada por Arendt em oposição ao poder, sendo de natureza instrumental, enquanto o poder é racional e intersubjetivo (SINTOMER, 1994, p. 117-118). Mas, apesar disso, a violência sempre esteve presente como elemento constituinte da ação estatal, o que leva Arendt a reconhecer, weberianamente, que "a violência sempre foi a ultima ratio na ação política, e a força sempre foi a expressão visível do domínio e do governo" (ARENDT, 1989, p. 167).

Tomemos a seguinte afirmativa da autora: "Somente a pura violência é muda, e por este motivo a violência, por si só, jamais pode ter grandeza" (ARENDT, 1981, p. 35). A política grega, segundo ela, nasce da palavra e, portanto, pressupõe a discussão e exclui a violência. A palavra como fundamento da política é, assim, um fundamento a ser resguardado.

Montesquieu (1973, p. 124) antecipa aspectos da tipologia arendtiana ao distinguir entre autoridade e despotismo, afirmando:

A monarquia arruina-se quando o príncipe, relacionando tudo unicamente a si, chama Estado à sua capital, capital à sua corte, $\mathrm{e}$ corte à sua única pessoa. Enfim, ela se arruina quando um príncipe desconhece sua autoridade, sua situação, o amor de seus súditos, e quando não percebe que o monarca deve julgar-se em segurança, como um déspota deve crer-se em perigo.

A autoridade, como acentua Montesquieu, nasce não da força e, sim, da legitimidade; pressuposto arendtiano. E é fundamental para a compreensão do pensamento político da autora a distinção feita por ela entre força e autoridade: "Visto que a autoridade sempre exige obediência, ela é comumente confundida com alguma forma de poder ou violência. Contudo, a autoridade exclui a utilização 
de meios externos de coerção; onde a força é usada, a autoridade em si mesmo fracassou" (ARENDT, 1972, p. 129).

Outra questão a ser colocada é: o que é o espaço público para Arendt? A praça de uma cidade pode não ser definida como tal, mas uma sala de jantar na qual dissidentes reúnam-se pode ser assim considerada. Espaços públicos, em síntese, são locais de discussão e persuasão (BENHABIB, 1996, p. 78). E, para Arendt, a esfera pública da linguagem e da ação, lembra Bhabha (1999, p. 205), é o teatro para a manifestação das capacidades humanas. Temos, portanto, uma perspectiva ampliada do conceito de esfera pública, ao qual Laisner (1998, p. 95) refere-se ao descrever de que modo, nos textos da autora, "o espaço público se qualifica como o espaço de deliberação conjunta, no qual os homens tornam-se interessados e responsáveis pelas questões que dizem respeito a um destino comum".

A esfera política, para Arendt, não coincide necessariamente, como ressalta Ortega (2000, p. 227), com a esfera estatal. Pelo contrário, para ela, "agir é começar, experimentar, criar algo novo, o espaço público como espaço entre os homens pode surgir em qualquer lugar, não existindo um locus privilegiado". Mas o espaço público diferencia-se do espaço particular por ser o espaço onde ocorre a ação política e Arendt vê o desaparecimento da distinção entre espaço público e espaço privado como uma catástrofe presente no horizonte da modernidade.

Como definir, ainda, o conceito arendtiano de mundo? "Para Arendt, o mundo é então esse espaço criado pela reunião dos homens, um espaço que, simultaneamente, se intercala entre eles, lhes separa; o mundo é um entre-dois, um espaço intermediário no qual se dão os negócios humanos" (COURTINE-DENAMY, 2004, p. 95). E a política é definida por Arendt como um agir no mundo: "A principal distinção, em termos políticos, entre Pensamento e Ação reside no fato de que, quando estou pensando, estou apenas com o meu próprio eu ou com o eu de outra pessoa, ao passo que estou na companhia de muitos assim que começo a agir" (ARENDT, 2004, p. 171). O mundo é visto por Arendt como um espaço político e, por isso mesmo, perecível. É um conjunto compartilhado de instituições e leis sujeito ao desaparecimento em determinadas situações (DUARTE, 2002, p. 64). 
Já a política é, para Arendt, o espaço da diferença. Segundo ela, "a política trata da convivência entre diferentes. Os homens se organizam politicamente para certas coisas em comum, essenciais num caos absoluto, ou a partir do caos absoluto das diferenças" (ARENDT, 1999a, p. 21). E a opinião pública pode, nesse sentido, anular o espaço da política. Isso porque a vontade majoritária da opinião pública não é, para Arendt, necessariamente democrática. Pode, mesmo, ser antidemocrática, se pensarmos a democracia como espaço de convivência entre vontades divergentes e de tolerância em relação a expressões minoritárias. Assim, uma tirania apoiada pelo povo torna estéreis as vozes que dela discordem. E ela conclui:

Não é apenas, e talvez não seja fundamentalmente, em razão do poder esmagador da maioria que a voz da minoria perde, nessas circunstâncias, toda a força e toda a plausibilidade; a opinião pública, por causa de sua unanimidade, provoca uma oposição unânime e, por conseguinte, sufoca as verdadeiras opiniões que surjam em qualquer lugar (ARENDT, 1988, p. 180).

Como Young-Bruhel (1997, p. 287) soube perceber, a política é, para Arendt, o oposto da solidão exatamente por ser o espaço da pluralidade: "A pluralidade é o sine qua non da ação. A ação é dependente da presença constante dos outros, requer um espaço público". E Arendt pensa a ação política como ação que extrai sua dignidade de sua capacidade de fundar novos mundos (CORREIA, 2001, p. 237). Como acentua Bignotto (2001, p. 118), "os atos de fundação são, para Arendt, as ações livres mais importantes que podemos levar a cabo, uma vez que derivam diretamente de nossa capacidade, única na natureza, de começarmos repetidamente a obra de nossa própria condição". Não se trata, porém, de postular um retorno utópico aos momentos de fundação: "Arendt sabe muito bem que o passado não é recuperável; tudo que ela quer é um eterno retorno dos homens do presente à virtude cívica e política que periodicamente se manifesta nos feitos de grandes homens" (EISENBERG, 2001, p. 173).

Arendt, lembra Canovan (1994, p. 187), é resolutamente contra qualquer forma de maquiavelismo vulgar, opondo-se à validade do uso de qualquer meio que vise ao triunfo de uma boa causa. Seu 
pensamento segue, portanto, padrões éticos que a levam a relativizar, por exemplo, os conceitos usuais de vitória e de derrota, encarando a vitória de uma revolução como uma derrota, ao comprometer os princípios e promessas que a justifiquem. E a derrota pode, ainda, ser melhor que a vitória para um país, desde que esta signifique a liquidação dos princípios morais que o fundamentam e - por que não? - o justificam. Foi o que aconteceu com os Estados Unidos em seu envolvimento no caso do Vietnã, se seguirmos as esperanças demonstradas por ela em carta a Heidegger, datada de 1967: "O melhor que pode acontecer com este país, ou seja, com a república, é perder a guerra. Isso terá consequiências muito desagradáveis, que precisam ser, contudo, tiradas para a aventura imperialista e para a sangrenta Pax Americana" (Arendt apud LUDZ, 2001, p. 121).

Ela critica, por fim, a concepção que fundamenta os direitos humanos na natureza, recusando qualquer forma de jusnaturalismo. Segundo Duarte (2000, p. 48), "sua crítica não se dirige à idéia dos direitos humanos enquanto tais, mas ao pressuposto segundo o qual tais direitos encontrariam seu fundamento na natureza do homem, implicando-se assim uma redução da política à natureza”.

Dessas questões e respostas surge, assim, uma autora assumida e propositadamente excêntrica, ou seja, à margem de qualquer centro político dominante. Arendt, afinal, lembra Laqueur (1998, p. 496), tinha uma vaga simpatia pela esquerda e pelos revolucionários, embora, em carta a Jaspers, acentue ser a margem da sociedade o único lugar possível, nos tempos contemporâneos, para seres humanos decentes. E é exatamente a sua excentricidade que torna indispensável a distância a ser mantida perante uma leitura de fundo ideológico de seus textos, baseada no contexto ideológico da Guerra Fria e que buscou apropriar-se de suas idéias a partir de um anticomunismo estreito que buscou, nesses textos, uma forma de justificativa. Afinal, se a autora foi crítica incisiva de uma certa esquerda de cunho dogmático, não se encaixa bem no figurino reacionário o entusiasmo com o qual ela saudou a Revolução Húngara e a experiência dos conselhos nela elaborada, o que a levou a exaltála em carta enviada, no período, a Mary McCarthy: "Finalmente, finalmente eles precisaram mostrar as coisas como realmente são" (Arendt apud YOUNG-BRUHEL, 1997, p. 270). 
Arendt defende a existência do que podemos chamar de política sem piedade; uma política anticristã. Isso porque a valorização da caridade como suprema virtude implica em uma desvalorização da esfera pública; daí, acentua Arendt (1981, p. 84), a hostilidade com a qual o cristianismo sempre a encarou. $\mathrm{O}$ amor, para ela, é uma entidade apolítica, devido à sua inclinação natural a excluir o que a autora considera ser a essência da política (CHIRA, 1995, p. 507). E a compaixão não é o espaço da política, e vice-versa. A compaixão demanda ação direta e rápida, oposta aos longos processos de negociação e acordo que caracterizam a política, cuja argumentação é inteiramente estranha à compaixão. Do ponto de vista político, portanto, ela é irrelevante e inconsequiente (ARENDT, 1988, p. 68).

E mesmo quando um processo revolucionário enfrenta o sofrimento dos miseráveis, tal enfrentamento gera, por sua vez, na perspectiva da autora, problemas que Cadoni (1996, p. 90) busca identificar: "Superar esse sofrimento através da compaixão significa excluir o diálogo e a argumentação da cena política e substituí-los pela imediaticidade da força”. Por fim, a compaixão provoca ainda, em termos políticos, consequiências daninhas: "Pela lógica perversa da piedade, a miséria legitima a mesma dissimetria de poder que a gerou" (idem, p. 97). Assim, as revoluções européias, para Arendt, radicalizaram a política e deram contornos ideológicos à compaixão (HEUER, 2005, p. 51), o que a autora acentua, ao afirmar que: "Não podemos discutir aqui o dano que a compaixão introduziu nas revoluções modernas, com as tentativas de melhorar o quinhão dos infelizes, ao invés de estabelecer justiça para todos" (ARENDT, 1987, p. 22).

A atividade política não deve privilegiar, portanto, questões materiais, e o sofrimento dos pobres é algo que não lhe diz respeito. Embora possa parecer chocante, tal axioma é fundamental para a compreensão do pensamento político arendtiano e é exposto com toda a ênfase: "Nada, podemos hoje afirmar, pode ser mais obsoleto do que a tentativa de libertar a humanidade da pobreza por meios políticos; nada pode ser mais inútil e mais perigoso" (ARENDT, 1988, p. 90).

Se Arendt define, como fica nítido, a piedade como um sentimento pré-político por pertencer a uma esfera privada de valores, uma outra questão, contudo, deve ser confrontada, qual seja, a de 
sua efetiva relação com um regime democrático. Na medida em que Arendt pensa a política como uma esfera relacionada ao debate e não à busca de soluções para o mundo das necessidades econômicas, ela não consegue oferecer soluções, por exemplo, para o deslocamento sentido de forma tão premente na sociedade contemporânea entre a esfera política e a esfera na qual vivem os cidadãos. Resta, enfim, a urgente construção de um caminho que transforme a piedade em um sentimento ativo político e transformador, refutando, talvez, um paradigma arendtiano, mas construindo, a partir daí, uma democracia capaz de radicalizar e aprofundar seus pressupostos.

Se, por outro lado, Arendt recusa-se a relacionar a compaixão com a esfera política e recusa-se, igualmente, a inserir o labor no campo da atividade política, é porque as massas e suas necessidades são por ela associadas à ascensão do totalitarismo, ocasionando, assim, um trauma histórico que cabe ao pensamento político, tal como delineado a partir da perspectiva da autora, compreender e superar. Assim, As origens do totalitarismo faz parte desse projeto de compreensão, ao passo que a parte mais teórica da obra da autora busca lançar os fundamentos de uma política pós-totalitária. Mas, nessa política, as massas ocupam um lugar incerto, associado ao trabalho e à piedade, com a conexão entre a atividade produtiva e a democracia permanecendo tênue até o fim.

\section{2}

Todo regime burocrático, para Arendt, é intrinsecamente antidemocrático:

A burocracia é sempre um governo de peritos, de uma "minoria experiente", que tem de resistir da melhor forma possível à constante pressão da "maioria inexperiente". Todo povo é basicamente formado por uma maioria inexperiente e, portanto, não se lhe pode confiar um assunto tão altamente especializado como política e negócios públicos (ARENDT, 1989, p. 245).

E o risco contemporâneo, para Arendt, é a transformação de todos os governos em burocracias: 
O governo que não é nem da lei, nem dos homens, mas de escritórios ou computadores anônimos, cuja dominação inteiramente despersonalizada pode vir a se tornar uma ameaça maior à liberdade e àquele mínimo de civilidade sem o qual nenhuma vida comunitária é concebível, do que jamais foi a mais abusiva arbitrariedade dos tiranos do passado (ARENDT, 2004, p. 66).

Em oposição a tal forma de regime, Arendt estabelece, segundo Collin (1992, p. 40), dois modelos de democracia: um, de origem iluminista, inscreve a pluralidade na homogeneidade; o outro, que ela identifica com o regime político norte-americano, distingue cidadania e identidade, igualdade e diferença. $\mathrm{E}$ a tradição americana, na perspectiva arendtiana, possui, segundo Heller e Fehér (1998, p. 152), um novo reino como promessa: "Com um novo reino de liberdade, o pária será elevado e o privilegiado reduzido ao nível do cidadão, que é o nível da liberdade. E independente de elevado ou reduzido a esse nível, a liberdade só pode ser, por definição, um ganho, jamais uma perda".

Já a democracia de massas, tal como vista por Arendt, pode ser pensada como uma forma de perversão de seu ideal político, na medida em que, segundo Flynn (1992, p. 121), ela é pensada pela autora, em termos administrativos, como uma enorme organização econômica apenas eventualmente contestada pelo reaparecimento episódico do genuíno espaço público. Nela, perverte-se a ação política que, tal como vista por Arendt, caracteriza-se pela pluralidade. A história de um ator político é a história de outros atores e seus planos e ações nunca são determinados apenas por ele próprio (NYE, 1994, p. 192).

O regime democrático, segundo Arendt, caracteriza-se pela abertura e permanência de espaços de debate e comunicação determinados pela pluralidade humana, ou, nas palavras da autora, "no governo constitucional, as leis positivas destinam-se a erigir fronteiras e a estabelecer canais de comunicação entre os homens, cuja comunidade é continuamente posta em perigo pelos novos homens que nela nascem" (ARENDT, 1989, p. 517). Ele é, portanto, um regime caracterizado pela liberdade e pela ação, só possível a partir mesmo da liberdade, o que gera, contudo, a necessidade de formular novas questões. 
Qual a importância da liberdade para Arendt? Segundo Figueiredo (2002, p. 394), "a condição humana caracteriza-se pelo mérito intrínseco da liberdade e da ação livre, que a necessidade própria ser da natureza, que o homem também é, não pode ferir. É essa noção de liberdade, como espontaneidade incondicionada dos seres humanos individuais e interagentes, o nervo do pensamento arendtiano". E a liberdade, para Arendt, como acentua Lebrun (1983, p. 55), é um conceito distinto do conceito de soberania: "Ela é invenção, virtuosismo, réplica feliz aos acasos da vida, enquanto o querer não é senão tirânico".

A ação política para Arendt, desenvolve-se, segundo Souki (1998, p. 44), no terreno da liberdade e da pluralidade: "A criatividade da ação política é assinalada pelo exercício contínuo da liberdade pública, que faz avançar e viver as instituições. O campo da liberdade é o do pensamento plural, é o pensar no lugar e na posição do outro". Mas, afinal, de qual liberdade se trata? A liberdade à qual se refere Arendt não é, segundo Lafer (1979, p. 72), a liberdade interior, que é vista por ela como derivativa, fruto da retração ou da reclusão em relação ao mundo público, que é onde política e liberdade se articulam. E Lafer (1979, p. 32) acentua, ainda, o significado do conceito para a autora: "Liberdade, para Hannah Arendt, é a liberdade antiga, relacionada com a polis grega. Significa liberdade para participar, democraticamente, do espaço público da palavra e da ação".

Reis (2000, p. 27), por outro lado, menciona a existência, no pensamento de Arendt, de "uma singular dignificação da esfera política em que a ação desenvolvida em público através de um processo de comunicação livre entre iguais passa a ser constitutiva dela, ou seja, em que liberdade e igualdade passam a integrar a própria definição da política”. Mas, se liberdade e política, para Arendt, são indissociáveis, liberdade e necessidade também o são: "O homem que ignora ser sujeito à necessidade não pode ser livre, uma vez que sua liberdade é sempre conquistada mediante tentativas, nunca inteiramente bem-sucedidas, de libertar-se da necessidade" (ARENDT, 1981, p. 133). E Focher (2000, p. 166), por fim, acentua como, no pensamento de Arendt, política e liberdade caminham pari passu, sendo correlacionadas como uma expressão unitária, sendo a crise de uma a crise da outra. 
A liberdade é o território da ação, e esta, segundo Arendt, é intrinsecamente humana: "Só a ação é prerrogativa exclusiva do homem; nem um animal nem um deus é capaz de ação, e só a ação depende inteiramente da constante presença de outros" (ARENDT, 1981, p. 31). Qualquer ação gera, ainda, um processo interminável e nele se insere: "O processo de um único ato pode prolongar-se literalmente, até o fim dos tempos, até que a própria humanidade tenha chegado ao fim" (idem, p. 245). Como consequiência, a realidade, derivada da ação, torna-se imprevisível e infinitamente complexa: "É da própria natureza de todo novo início o irromper no mundo como uma improbabilidade infinita, e é, contudo, justamente esse infinitamente improvável que constitui de fato a verdadeira trama de tudo que denominamos de real" (ARENDT, 1972, p. 218). E, a partir desse pressuposto, ela cria uma teoria da ação, ao afirmar:

Pelo fato de que se movimenta sempre entre e em relação a outros seres atuantes, o ator nunca é simples agente, mas também, e ao mesmo tempo, paciente. Agir e padecer são como as faces opostas da mesma moeda, e a história iniciada por uma ação compõe-se de seus feitos e dos sofrimentos deles decorrentes (ARENDT, 1981, p. 203).

A liberdade é, também, e intrinsecamente, a liberdade de dizer não. Nos anos 1960, Arendt identifica a tradição republicana norte-americana não com o sistema partidário que é, afinal, dela proveniente, mas com a contestação civil: "Minha discussão é que os contestadores civis não são mais que a derradeira forma de associação voluntária, e que deste modo eles estão afinados com as mais antigas tradições do país” (ARENDT, 1999b, p. 85). E trata-se, ainda, de fenômeno estritamente nacional: "Desobediência civil e associação voluntária são fenômenos praticamente desconhecidos em qualquer outro lugar" (idem, p. 87).

Mas a liberdade pressupõe, também, a reflexão capaz de validar a ação humana e, onde tal reflexão inexiste, abre-se o caminho para a morte da liberdade. Dessa forma, o elogio à desobediência civil levada adiante nos anos 1960 é conectado, por Arendt, à sua constatação da existência do mal extremo personificado por Eichmann e por sua recusa em refletir acerca de suas ações. Isso porque, quando os jovens americanos recusam-se a ir lutar no Vietnã, eles 
estão recusando-se a participar das ações de um regime nefasto, endossando-o (COURTINE-DENAMY, 2004, p. 76); algo que Eichmann não fez, o que simboliza o verdadeiro crime cometido pelos criminosos de guerra, assim como pela burguesia, que foi, segundo Arendt, a recusa em pensar (RING, 1991, p. 436).

Expressando-se apenas a partir de clichês e estereótipos, Eichmann representa a incapacidade de experimentar o mundo e, portanto, a impossibilidade do agir político, o que Telles (1990, p. 29) acentua: "Neste caso, a perda do espaço público significa a privação de um mundo compartilhado de significações a partir do qual a ação e a palavra de cada um podem ser reconhecidas como algo dotado de sentido e eficácia na construção de uma história comum". Se Arendt, portanto, situa a violência em oposição à ação política, a desobediência civil é vista por ela como a ação política por excelência, conectando-a ao republicanismo ligado às tradições americanas (COHEN \& ARATO, 1992, p. 595-596).

A liberdade é a liberdade de pensar e de influenciar o mundo a partir de ações que expressem o pensamento. A partir de tal pressuposto, Arendt define liberdade de expressão como o direito do indivíduo de expressar sua opinião, com o objetivo de convencer outras pessoas da validade da mesma (ARENDT, 1992, p. 39). De refletir sobre o mundo que o cerca, portanto, e, a partir de tal reflexão, expressar suas conclusões. Mas o que acontece quando tal reflexão ignora o mundo?

Se o pensar ricocheteia sobre si mesmo e encontra seu único objeto na própria alma, torna-se reflexão, e sem dúvida adquire (desde que permaneça racional) uma semelhança de poder ilimitado, ao mesmo tempo precisamente em que se isola do mundo, se desinteressa deste, entrincheira-se diante do único objeto "interessante": o próprio interior (ARENDT, 1993, p. 21).

\section{3}

Arendt pode ser vista, segundo Canovan (1978, p. 6), ao mesmo tempo, como uma proeminente teórica da participação democrática e como uma elitista de intensidade nietzscheniana. Seu conceito de democracia não exclui, portanto, a necessidade 
de existência de elites, bem como de seu domínio, tomando-o, mesmo, como pressuposto, com o aprofundamento da igualdade e a democratização da participação política favorecendo, segundo Arendt, a corrupção e degradação da esfera na qual os novos membros são admitidos:

A corrupção e a perversão são mais perniciosas e, ao mesmo tempo, mais suscetíveis de ocorrer, numa república igualitária do que em qualquer outra forma de governo. Falando esquematicamente, esses males passam a ocorrer quando os interesses particulares invadem o domínio público, isto é, quando eles vêm de baixo, e não de cima (ARENDT, 1988, p. 201).

O conceito de igualdade, quando imposto a grupos que não se reconhecem como iguais, gerou, no século XX, terríveis consequiências: "É pelo fato de a igualdade exigir que eu reconheça que todo e qualquer indivíduo é igual a mim que os conflitos entre grupos diferentes, que por motivos próprios relutam em reconhecer no outro essa igualdade básica, assumem formas tão terrivelmente cruéis" (ARENDT, 1989, p. 77). E, referindo-se à questão da igualdade, Arendt termina por fazer um inequívoco elogio de seu oposto, ou seja, das sociedades aristocráticas:

O principal vício de toda sociedade igualitária é a Inveja - o grande vício da sociedade grega livre. E a grande virtude de todas as aristocracias parece-me ser que as pessoas sempre sabem quem são e portanto não se comparam com outras. Essa comparação constante é realmente a quintessência da vulgaridade (Arendt apud BRIGHTMAN, 1995, p. 170).

Vejamos, assim, como Arendt (1981, p. 187) pensa o que considera ser o mundo ideal: "O artifício humano deve ser um lugar adequado à ação e ao discurso, a atividades não só inteiramente inúteis às necessidades da vida, mas de natureza inteiramente diferente das várias atividades da fabricação mediante a qual são produzidos o mundo e todas as coisas que nele existem". Nesse trecho, de fundamental importância, Arendt explicita seu projeto político e ético; um projeto no qual o mundo do trabalho é situado em uma esfera distinta da política, vista como atividade a ser 
exercida de forma alheia à sobrevivência humana. Não é possível pensarmos, com base nisso, em aposta efetiva de Arendt na restauração da Antiguiidade Clássica, por ela associada a esse ideal, e a autora certamente foi lúcida o suficiente para não embarcar em tal projeto de restauração ou imaginar, mesmo que remotamente, sua viabilidade. Trata-se, porém, de um ideal por ela associado a um tipo de convivência que se perdeu e, aqui, como é usual em sua obra, Arendt prefere manter-se mais próxima a uma reconstrução do passado fundamentada nos ideais por ela defendidos que a uma reconstrução efetivamente histórica. Por outro lado, ainda, a autora não ignora a irreversibilidade das mudanças históricas e, se ela não chega a referir-se à existência de um mundo ideal que se perdeu, ela sente-se claramente deslocada em um mundo cada vez mais distante dos ideais políticos e de convivência humana por ela delineados.

Se o pensamento político arendtiano possui, dessa forma, um componente aristocrático, tal componente relaciona-se, de forma íntima, com a defesa e o elogio da tradição, feitos de forma enfática pela autora; com o reconhecimento de sua necessidade e com o caráter modelar atribuído por ela ao poder exercido na Antigüidade. Arendt (1981, p. 213), de fato, lembra que "a fundação de cidades que, como as cidades-estado, converteram-se em paradigmas para toda a organização política ocidental, foi na verdade a condição prévia material mais importante do poder." E, nesse sentido, Pocock (1975, p. 550) menciona o homo politicus descrito por Arendt como um ideal antigo no qual a sua virtude era um meio de ação política.

A tradição política ocidental, para Arendt, deriva do mundo greco-romano e extrai dele suas virtudes, suas práticas e seus conceitos. O conceito de política externa, por exemplo, ou seja, "a concepção de uma ordem política fora das fronteiras do próprio corpo do povo ou da cidade" foi, segundo Arendt, criado pelos romanos e corre o risco de desaparecer a partir do momento em que a guerra visar não mais a vencer, mas, sim, a exterminar o adversário: "Pois o que é exterminado numa guerra é muitíssimo mais que o mundo do adversário derrotado; é sobretudo o espaço intermédio entre os parceiros da guerra e entre os povos, que em sua totalidade formam o mundo na terra" (ARENDT, 1999a, p. 123). 
O espaço público grego, tal como descrito por Arendt, estrutura-se a partir de uma relação entre iguais. Segundo Lefort (1991, p. 69), "o poder exerce-se aí numa relação entre homens que é uma troca de falas, em vista de decisões que concernem a todos". Mas o próprio Lefort questiona a descrição idealizada feita pela autora, ao afirmar: "Seria admissível indagar ainda como, por trás da fachada da igualdade política, eram efetivamente tomadas as decisões, e por quais meios alguns homens conseguiam exercer uma autoridade duradoura sobre tal ou qual parte do povo" (idem, p. 73). Tal elogio, por fim, gera problemas percebidos com precisão por Carvalho (2002, p. 122) que, incluindo Arendt entre eles, menciona a existência de "autores contemporâneos que ainda defendem a importância da preservação da liberdade positiva dos antigos, mas dificilmente se encontra neles justificativa para o comportamento virtuoso que vá além da exortação moral ou de argumentos racionais sem força para mover as pessoas à ação".

A ruptura com a tradição - sua perda, a incapacidade de orientar-se politicamente a partir dela - é, para Arendt, o grande drama político contemporâneo; uma espécie de matriz de todos os males. Quais foram, para ela, por exemplo, as consequiências da ruptura da tradição ocorrida na Alemanha após o final da I Guerra?

Politicamente falando, foi o declínio e queda do Estado-nação; socialmente, foi a transformação de um sistema de classes numa sociedade de massas; espiritualmente, foi a ascensão do niilismo, que por longo tempo fora preocupação de poucos mas então, subitamente, se convertia em fenômeno de massas (ARENDT, 1987, p. 195).

Se a tradição é vista como algo a ser preservado e cuja perda é pensada em termos de catástrofe, a revolução não é, porém, pensada como o oposto da tradição. Pelo contrário, a revolução é pensada como renovação e restauração, como retorno a um início visto como ato de fundação. Por outro lado, se a revolução é, também, restauração, chegamos a uma questão colocada por Ricoeur (1995, p. 19), em sua análise do pensamento político arendtiano: "Restauração de um espaço político? Mas será que ele existiu historicamente alguma vez? Há um ponto em que a rememoração é também projeção para o futuro". 
E chegamos, aqui, a outra questão, qual seja: o que Arendt entende por revolução? Tomemos a distinção entre revolta e revolução proposta por Octavio Paz (1972, p. 262):

Em revolução as idéias de regresso e movimento se fundem na da ordem; em revolta essas mesmas idéias denotam desordem. Assim, revolta não implica nenhuma visão cosmogônica ou histórica: é o presente caótico ou tumultuoso. Para que a revolta cesse de ser alvoroço e ascenda à história propriamente dita, deve transformar-se em revolução.

Tal distinção retoma, em linhas gerais, o conceito arendtiano de revolução, pensada como algo distinto de uma mera rebelião contra um governante qualquer. Tal conceito, afinal, toma como fundamento a idéia de liberdade:

Somente onde ocorrer mudança, no sentido de um novo princípio, onde a violência for utilizada para constituir uma forma de governo completamente diferente, para dar origem à formação de um novo corpo político, onde a libertação da opressão almeje, pelo menos, a constituição da liberdade, é que podemos falar de revolução (ARENDT, 1988, p. 22).

E tal conceito gera, ainda, nova questão: o que gera as revoluções? Se a história, segundo Arendt, ensina algo sobre as causas das revoluções, que ensinamento será esse?

Será que a desintegração dos sistemas políticos precede às revoluções, que o sintoma claro de desintegração é uma progressiva erosão da autoridade governamental, e que essa erosão é causada pela incapacidade do governo em funcionar adequadamente, de onde brotam as dúvidas dos cidadãos sobre sua legitimidade (ARENDT, 1989, p. 64).

Mas as conclusões arendtianas são pessimistas. Segundo Arendt, Hegel pôde, ainda, postular o desenvolvimento histórico "em termos de um movimento dialético em relação à liberdade e, assim, compreender a Revolução Francesa e Napoleão Bonaparte”. São, contudo, ilusões perdidas e a história não permite vislumbrar nenhum horizonte de liberdade. Conclui ela, então: "Hoje nada pa- 
rece mais discutível do que a idéia de que o curso da história esteja, em si e por si mesmo, dirigido à crescente realização da liberdade. Se pensarmos em termos de tendências e correntes, bem mais plausível parece ser o oposto" (ARENDT, 1993, p. 88). As experiências totalitárias, a consolidação de uma sociedade de massas vista pela autora com incoercível desconfiança e o enfraquecimento da tradição como instância orientadora da ação política fazem o pensamento político arendtiano adquirir um tom de inequívoco desalento.

\section{4}

Marx efetua, segundo Arendt, ao glorificar a violência e ao situar o trabalho no centro da esfera política, uma negação radical dos pressupostos do pensamento grego. Afirma, então, a autora: "a teoria das superestruturas ideológicas, de Marx, assenta-se, em última instância, em sua hostilidade antitradicional ao discurso e na concomitante glorificação da violência" (ARENDT, 1972, p. 50). E é tal concepção que Arendt busca contestar, ao dissociar política, associando-a a reflexão e à ação individual, e atividade econômica, acentuando: "A sociedade é a forma na qual o fato da dependência mútua em prol da subsistência, e de nada mais, adquire importância pública, e na qual as atividades que dizem respeito à mera sobrevivência são admitidas em praça pública" (ARENDT, 1981, p. 56). Fazendo isso, porém, ela cria uma perspectiva aristocrática da polis, não mais aceitável.

Arendt diferencia, ainda, pensamento e cognição. Segundo ela, "a cognição sempre tem um fim definido, que pode resultar de considerações práticas ou de mera curiosidade; mas, uma vez atingido esse fim, o processo cognitivo termina”. Já o pensamento não é prático, não gera um conhecimento que possa tornar-se útil - isso é função da cognição - e a "filosofia utilitária do homo faber" não se cansa, segundo ela, de proclamar a inutilidade do pensamento (idem, p. 184).

O trabalho, segundo Arendt (1989, p. 527), é apolítico por definição: "O homem, como homo faber, tende a isolar-se com o seu trabalho, isto é, a deixar temporariamente o terreno da política". E, segundo ela, ainda, "historicamente, a última esfera pública, o 
último lugar de reunião que de alguma forma se relaciona com a atividade do homo faber, é o mercado de trocas onde seus produtos são exibidos" (ARENDT, 1981, p. 175). Para ela, a esfera privada corresponde ao trabalho e ao mercado, enquanto a esfera pública corresponde ao ócio e à assembléia. Arendt reafirma, assim, sua concepção aristocrática da política.

Tomemos a fundamental definição efetuada pela autora entre labor, trabalho e ação:

O labor assegura não apenas a sobrevivência do indivíduo, mas a vida da espécie. $O$ trabalho e seu produto, o artefato humano, emprestam certa permanência e durabilidade à futilidade da vida mortal e ao caráter efêmero do tempo humano. A ação, na medida em que se empenha em fundar e preservar corpos políticos, cria a condição para a lembrança, ou seja, para a história (idem, p. 16).

O trabalho diferencia-se do labor a partir da durabilidade de seus produtos: "Vistos como parte do mundo, os produtos do trabalho - e não os produtos do labor - garantem a permanência e a durabilidade sem as quais o mundo simplesmente não seria possível" (idem, p. 105). E o labor, diferentemente do trabalho, é incapaz, por si só, de estabelecer uma rede de relações sociais, já que o corpo, nele, "concentra-se apenas no fato de estar vivo, e permanece preso ao seu metabolismo com a natureza sem jamais transcender ou libertar-se do ciclo repetitivo do seu próprio funcionamento" (idem, p. 127). Por isso, finalmente, a atividade dos seres que a ele se dedicam é naturalmente limitada: "O animal laborans que, com o próprio corpo e a ajuda de animais domésticos, nutre o processo da vida, pode ser o amo e senhor de todas as criaturas vivas, mas ainda é servo da natureza e da terra; só o homo faber se porta como amo e senhor de toda a terra” (idem, p. 152).

É decisivo no pensamento de Arendt, como vemos, o contraste entre vida econômica e vida política, com a ação política dissociando-se da ação produtiva. Consiste, nas palavras de Jouvenel (1978, p. 193), em um "contraste que representa a discussão pública moderna, alimentada por todas as preocupações materiais que, segundo assevera essa escritora, costumavam permanecer na obscuridade familiar, mas hoje são espalhadas pela praça”. E con- 
siste, ainda, em estabelecer uma distinção entre público e privado que tem sido obscurecida nos tempos modernos por uma terceira categoria, definida por Arendt como "social", e por seu crescente domínio (CANOVAN, 1994, p. 115), sendo a sociedade vista por ela, acentua Canovam (idem, p. 120), em contraposição à possibilidade de uma república de cidadãos. Tais dicotomias, contudo, são claramente excludentes, e Heller (1991, p. 88) critica, na visão política de Arendt, o que define como a exclusão de uma ampla variedade de temas que pertencem ao cotidiano dos cidadãos.

Se a indistinção entre esfera política e esfera econômica e entre atividade pública e atividade particular corrói a dignidade da política, para usar uma expressão arendtiana, o totalitarismo, por fim, implica na própria negação da política e Arendt dedica parte considerável de sua obra ao afã de compreendê-lo, bem como à tarefa de definir suas origens, sendo o individualismo, na perspectiva arendtiana, a melhor garantia contra o totalitarismo, descrito por ela como a eliminação do espaço entre as pessoas.

$O$ poder independe, segundo Arendt, de fatores materiais, $o$ que gerou um impasse nas tentativas de compreender os regimes totalitários, em seu caráter não-utilitário e desprendido de interesses materiais:

Aqueles que compreendem corretamente a terrível eficiência da organização e da polícia totalitárias tendem a subestimar a força material dos países totalitários, enquanto aqueles que compreendem a esbanjadora incompetência da economia totalitária tendem a subestimar a força material, o potencial de poder que pode ser criado à revelia de todos os fatores materiais (ARENDT, 1989, p. 469).

Imperialismo e Estado-nação, para Arendt (idem, p. 157), são conceitos incompatíveis, uma vez que "a nação concebe as leis como produto da sua substância nacional que é única. E não é válida além dos limites do seu próprio território, não correspondendo aos valores e anseios dos outros povos". Mas nacionalismo e Estado-nação são conceitos igualmente incompatíveis, a partir da definição que Arendt (idem, p. 262) dá ao primeiro: "Em sua essência, o nacionalismo é a expressão dessa perversa transformação do Estado em instrumento da nação e da identificação do cidadão com o membro da nação". 
Segundo Arendt (idem, p. 168), "a burguesia, que durante tanto tempo fora excluída do governo pelo Estado-nação e, por sua própria falta de interesse, das coisas públicas, emancipou-se politicamente através do imperialismo". A partir de tal distinção, torna-se possível entender como, na perspectiva da autora, o imperialismo desvirtuou e degradou a ação política. Nele, "a força tornou-se a essência da ação política e o centro do pensamento político quando se separou da comunidade política à qual devia servir" (idem, p. 167). Degradando a política, o imperialismo abriu espaço ao totalitarismo, no qual os requisitos para a ação política primam pela ausência.

Se o imperialismo degradou a política, o anti-semitismo forneceu os mecanismos de exclusão a partir dos quais o inimigo necessário à consolidação do totalitarismo foi gerado. O problema, para Arendt (idem, p. 25), não foi exploração econômica, mas a exploração sem sentido político: "A riqueza que não explora deixa de gerar até mesmo a relação existente entre o explorador e o explorado; o alheamento sem política indica a falta do menor interesse do opressor pelo oprimido". Foi nessa armadilha, segundo Arendt (idem, p. 35), que os judeus europeus caíram durante a era imperialista, na qual "o elemento judeu, intereuropeu e não nacional, tornou-se objeto de ódio, devido à sua riqueza inútil, e de desprezo, devido à sua falta de poder". No totalitarismo, enfim, temos a figura do outro transformada em inimigo a ser eliminado, enquanto a democracia só existe na pluralidade.

A análise do totalitarismo empreendida pela autora toma como base a existência de uma sociedade caracterizada pela atomização, mas tal pressuposto é eminentemente conservador, efetuando uma rígida distinção entre hierarquia e igualdade social e fazendo o elogio da ordem social hierárquica. É um pressuposto derivado de uma teoria social conservadora e, estudando as origens de tal teoria e localizando-a nas obras de Tarde, Le Bon e Ortega y Gasset, entre outros, Ortega (1991, p. 76-77) acentua seus fundamentos: "O indivíduo, imerso na massa, perderia sua identidade, sendo tragado pela consequiência coletiva de um ser que o transcende e o domina. [...] A multidão, ao se rebelar contra seu destino, isto é, sua subalternidade, desequilibraria um estado de harmonia secular". 
Arendt não teria, a meu ver, dificuldade em concordar com tal análise, que se coaduna com o caráter conservador e aristocrático de seu pensamento. Mas o republicanismo da autora, por outro lado, soube acentuar a importância de preservar determinadas tradições políticas que, de fato, funcionam como alicerces de uma democracia a ser vista em permanente construção.

Recebido em 25.12.2006

Aprovado em 18.02.2007

\section{Referências bibliográficas}

ARENDT, H. Entre o passado e o futuro. São Paulo: Perspectiva, 1972. Universitária, 1981.

A condição humana. Rio de Janeiro: Forense . Da violência. Brasília: UNB, 1985.

das Letras, 1987.

. Homens em tempos sombrios. São Paulo: Companhia

. Da revolução. São Paulo: Ática, 1988.

. Origens do totalitarismo. São Paulo: Companhia das Letras, 1989.

. Lectures on Kant's Political Philosophy. Chicago: The University of Chicago Press, 1992.

. A dignidade da política: ensaios e conferências. Rio de Janeiro: Relume Dumará, 1993.

1999a.

. O que é política? Rio de Janeiro: Bertrand Brasil, . Crises da República. São Paulo: Perspectiva, 1999b.

. Responsabilidade e julgamento. São Paulo: Companhia das Letras, 2004.

BENHABIB, S. Models of Public Space: Hannah Arendt, the Liberal Tradition, and Jurgen Habermas. In: CALHOUN, C. (ed.). Habermas and the Public Sphere. Cambridge: The MIT Press, 1996. 
BHABHA, H. K. The Postcolonial and the Postmodern: the Question of Agency. In: DURING, S. (ed.). The Cultural Studies Reader. London: Routledge, 1999.

BIGNOTTO, N. Totalitarismo e liberdade no pensamento de Hannah Arendt. In: MORAES, E. J. \& BIGNOTTO, N. (orgs.). Hannah Arendt: diálogos, reflexões, memórias. Belo Horizonte: UFMG, 2001.

BRIGHTMAN, C. Entre amigas: correspondência entre Hannah Arendt e Mary McCarthy. Rio de Janeiro: Relume Dumará, 1995.

CADONI, S. N. C. A lógica da compaixão. Idéias, Campinas, ano 3, n. 2, p. 69-107, 1996.

CANOVAN, M. The Contradictions of Hannah Arendt's Political Thought. Political Theory, London, v. 6, n. 1, p. 5-26, 1978.

. Hannah Arendt: a Reinterpretation of Her Political Thought. Cambridge: Cambridge University Press, 1994.

CARVALHO, J. M. Cidadania na encruzilhada. In: BIGNOTTO, N. (org.). Pensar a República. Belo Horizonte: UFMG, 2002.

CHIRA, S. Hannah Arendt on Love and Political: Love, Friendship, and Citizenship. The Review of Politics, Indiana, v. 57, p. 505-535, 1995.

COHEN, J. L. \& ARATO, A. Civil Society and Political Theory. Cambridge: The MIT Press, 1992.

COLLIN, F. Agir et donné. In: ROVIELLO, A-M. \& WEYEMBERGH, M. (eds.). Hannah Arendt et la modernité. Paris: Librairie Philosophique J. Vrin, 1992.

CORREIA, A. O desafio moderno: Hannah Arendt e a sociedade de consumo. In: MORAES, E. J. \& BIGNOTTO, N. (orgs.). Hannah Arendt: diálogos, reflexões, memórias. Belo Horizonte: UFMG, 2001.

COURTINE-DENAMY, S. O cuidado com o mundo: diálogo entre Hannah Arendt e alguns de seus contemporâneos. Belo Horizonte: UFMG, 2004.

DUARTE, A. $O$ pensamento à sombra da ruptura: política e Filosofia em Hannah Arendt. Rio de Janeiro: Paz e Terra, 2000.

. Hannah Arendt e a modernidade: esquecimento e redescoberta da política. In: CORREIA, A. (org.). Transpondo o 
abismo: Hannah Arendt entre a Filosofia e a política. Rio de Janeiro: Forense Universitária, 2002.

EISENBERG, J. Comunidade ou política? Hannah Arendt e as linguagens do pensamento político contemporâneo. In: MORAES, E. J. \& BIGNOTTO, N. (orgs.). Hannah Arendt: diálogos, reflexões, memórias. Belo Horizonte: UFMG, 2001.

FIGUEIREDO, L. O pensamento político de Hannah Arendt: uma revolução copernicana? Revista Portuguesa de Filosofia, Braga, v. 8, fasc. 2, p. 379-400, 2002.

FOCHER, F. Libertà e teoria dell'ordine politico. Machiavelli, Guicciardini e altri studi. Parma: Universitá di Parma, 2000.

FLYNN, B. The Concept of the Political and Its Relationship to Plurality in the Thought of Arendt. In: ROVIELLO, A-M. \& WEYEMBERGH, M. (eds.). Hannah Arendt et la modernité. Paris: Librairie Philosophique J. Vrin, 1992.

HELLER, A. \& FEHÉR, F. A condição política pós-moderna. Rio de Janeiro: Civilização Brasileira, 1998.

HEUER, W. La creatividad del exilio. La elaboración de un republicanismo existencial por Hannah Arendt e Heinrich Blïcher. Estudos de História, Franca, v. 12, n. 1, 2005.

JOUVENEL, B. As origens do Estado moderno: uma história das idéias políticas no século XIX. Rio de Janeiro: Zahar, 1978.

LAFER, C. Hannah Arendt: pensamento, persuasão e poder. Rio de Janeiro: Paz e Terra, 1979.

LAISNER, R. O debate sobre a construção da democracia no Brasil: contribuições teóricas de Hannah Arendt. Temáticas, Campinas, $\mathrm{n}$. 11-12, p. 91-108, 1998.

LAQUEUR, W. The Arendt Cult: Hannah Arendt as Political Commentator. Journal of Contemporary History, London, v. 33, n. 4, p. 483-496, 1998.

LEBRUN, G. Passeios ao léu. São Paulo: Brasiliense, 1983.

LEFORT, C. Pensando o político: ensaios sobre democracia, revolução e liberdade. Rio de Janeiro: Paz e Terra, 1991. 
LUDZ, U. (org.). Hannah Arendt-Martin Heidegger: correspondência, 1925-1975. Rio de Janeiro: Relume Dumará, 2001.

MONTESQUIEU. Do espírito das leis. São Paulo: Abril Cultural, 1973.

NYE, A. Philosophia: the Thought of Rosa Luxemburg, Simone Weil and Hannah Arendt. Routledge: New York, 1994.

ORTEGA, F. Hannah Arendt, Foucault e a reinvenção do espaço público. Trans/Form/Ação, São Paulo, v. 24, p. 225-236, 2000.

PAZ, O. Signos em rotação. São Paulo: Perspectiva, 1972.

POCOCK, J. G. A. The Machiavellian Moment: Florentine Political Thought and the Atlantic Republic Tradition. Princeton: Princeton University Press, 1975.

REIS, F. W. Política e racionalidade: problemas de teoria e método de uma Sociologia crítica da política. Belo Horizonte: UFMG, 2000.

RICOEUR, P. Leituras 1: em torno ao político. São Paulo: Loyola, 1995. RING, J. The Pariah as Hero: Hannah Arendt's Political Actor. Political Theory, London, v. 19, n. 3, p. 433-452, 1991.

SINTOMER, Y. Pouvoir et autorité chez Hannah Arendt. L'Homme et la Societé, Paris, n. 113, p. 117-131, 1994.

SOUKI, N. Hannah Arendt e a banalidade do mal. Belo Horizonte: UFMG, 1998.

TELLES, V. S. Espaço público e espaço privado na constituição do social: notas sobre o pensamento de Hannah Arendt. Tempo Social, São Paulo, v. 2, n. 1, p. 23-48, 1990.

WAGNER, E. S. Hannah Arendt \& Karl Marx: o mundo do trabalho. Cotia: Ateliê Editorial, 2002.

YOUNG-BRUHEL, E. Por amor ao mundo: a vida e a obra de Hannah Arendt. Rio de Janeiro: Relume Dumará, 1997. 
